Journal of Molecular Genetics 2(3-4): 32-35, 2010

ISSN: $2070-4267$

(C) Medwell Journals, 2010

\title{
Comparison of Rapid DNA Extraction Techniques for Conventional PCR-RFLP Analysis from Mammalian Whole Blood Cells
}

\author{
${ }^{1} \mathrm{~N}$. Asadzadeh, ${ }^{2}$ A. Javanmard and ${ }^{3}$ M.R. Nassiry \\ ${ }^{1}$ Department of Animal Genetics and Breeding, \\ Animal Science Research Institute of Iran (ASRI), Karaj, Iran \\ ${ }^{2}$ Biotechnology Laboratory, \\ East Azarbyjan Agriculture and Natural Resource Research Center, Tabriz \\ ${ }^{3}$ Department of Animal Science, Ferdowsi University, Mashad, Iran
}

\begin{abstract}
Clean, high molecular weight DNA is pre-requisite for DNA markers. The amount and quality of DNA is a crucial point for all further analysis. A unique advantage of these PCR techniques is the rapid DNA analysis of many animal samples using small quantities of DNA. Thus, a simple and rapid DNA extraction method is needed for studies such as genetic analysis that require large populations. Several methods for minimizing the DNA extraction steps have been reported but they require a large amount of animal tissues. In addition, bleeding and management of sampling and storage of the blood sample in freezers is often difficult due to space constraints. To overcome these problems, some techniques developed a DNA extraction method using the milk or hair root or semen. Researchers compared 4 methods of rapid DNA extraction with isolations of mammalian whole blood samples. DNA extraction methods included boiling, salting out, phenol-chloroform and silica gel procedures. Spectrophotometry and gel monitoring evaluated the DNA yield and purity for the 4 methods. The silica gel and phenol-chloroform methods yielded significantly purity and higher concentration of extracted DNA compared with other DNA extraction methods.
\end{abstract}

Key words: DNA extraction, DNA fingerprint, PCR, RFLP, target gene, Iran

\section{INTRODUCTION}

Generally, DNA quality is indicated by the absence of contaminating RNA, protein, lipids and other cellular constituents that may interfere with restriction enzymes, ligases and thermostable DNA polymerases (Berthomieu and Meyer, 1991; Williams et al., 1990). The large size of mammalian genomic DNA also requires that the isolation method be gentle enough to minimize mechanical shear stress which would fragment the large genomic DNA during the course of purification (Jeanpierre, 1987; Merante et al., 1999; Reymond, 1987). Commonly used procedures employ a buffer containing one or several detergents for example, SDS, NP-40 or Triton X-100.

This detergent lyses cells and assist in the removal of proteins from the DNA. More through deproteinization is achieved by the use of proteinase $\mathrm{K}$ in the lysis buffer. This enzyme is active in the presence of SDS and remains functional at elevated temperature (56-65). Under these conditions denatured or partially denatured proteins are more easily digested by proteinase $\mathrm{K}$. In contrast, most other enzymes (e.g., DNases) are denatured under these conditions. Pure DNA can simply be obtained by a single precipitation with isopropanol following proteinase $\mathrm{K}$ treatments. Residual protein and contaminating lipids can be effectively removed by extraction with phenol and chloroform.

Treating the sample with DNase-free. RNase followed by a chloroform extraction to remove the RNase can easily degrade contaminating RNA. By the addition of B-mercaptoethanol to a final concentration of $0.2 \%$ and by the addition of hydroxyauinolinto a final concentration of $0.1 \%$. The shelf life of phenol can be extended by storage at hydroxyquinoline also imparts a light orange color to the phenol, enabling easier phase recognition during extraction. DNases are dependent on $\mathrm{Mg}^{2+}$ and $\mathrm{Ca}^{2+}$ for activity. EDTA $\left(\mathrm{Ca}^{2+}\right.$ least $\left.2 \mathrm{~mm}\right)$ included in the DNA extraction buffer chalets these cations and thereby prevents the degradation and random nicking of high molecular weight DNA by Dnases.

Washing the cells with Phosphate-Buffered Saline (PBS) without $\mathrm{Mg}^{2+}$ and $\mathrm{Ca}^{2+}$ minimizes the activities of DNases for the same reason. Isoamyl alcohol is added to

Corresponding Author: N N. Asadzadeh, Department of Animal Genetics and Breeding, Animal Science Research Institute of Iran (ASRI), Karaj, Iran 
the chloroform to prevent foaming. In this study, comparison 4 rapid DNA extraction techniques from mammalian whole blood are described (Berthomieu and Meyer, 1991; Boom et al., 1990; Chikuni et al., 1997; Jeanpierre, 1987).

\section{MATERIALS AND METHODS}

Blood samples were randomly collected from 10 Iranian Sarabi cattle (Bos taurus). Authorized veterinarian collected blood samples for DNA genotyping from jugular. Blood was collected on $\mathrm{K}_{2}$ EDTA and stored at $-20^{\circ} \mathrm{C}$ for few weeks or $-70^{\circ} \mathrm{C}$ up to several months.

Boiling DNA extraction: This protocol was carried out according to the procedure described by Jeanpierre (1987). About $100 \mu \mathrm{L}$ bloods collected into $1.5 \mathrm{~mL}$ of microcentrifuge tube. To the above tube $500 \mu \mathrm{L}$ of lysis buffer (Sucrose: $0.32 \mathrm{M}$, Tris-HCl: $10 \mathrm{mM}, \mathrm{MgCl}_{2}: 5 \mathrm{mM}$, Triton $\times 100$ : $1 \%$ ) was added, vortex and centrifuged $(12000 \times \mathrm{g})$ for $1 \mathrm{~min}$ and washing was repeated once more. The above pellet was suspended with $100 \mu \mathrm{L}(\mathrm{NaOH}$ $50 \mathrm{mM}$ ) and was incubated at $100^{\circ} \mathrm{C}$ for $20 \mathrm{~min}$ then adds $20 \mu \mathrm{L}$ Tris- $\mathrm{Cl}(\mathrm{pH}=7.5)$ for concentration of DNA. Then inverts and centrifuged at $20 \mathrm{sec}$ and protein was precipitated and upper layer transmitted for other tube.

Salting out DNA extraction: This protocol was carried out according to the procedure described by Sambrook et al. (2000). About $100 \mu \mathrm{L}$ bloods collected into $1.5 \mathrm{~mL}$ of microcentrifuge tube. About $500 \mu \mathrm{L}$ of lysis buffer (Sucrose: $0.32 \mathrm{M}$, Tris-Hcl: $10 \mathrm{mM}$, $\mathrm{MgCl}_{2}$ : $5 \mathrm{mM}$,Triton $\times 100$ : $1 \%$ ) was added, vortex and centrifuged $(12000 \times \mathrm{g})$ for $1 \mathrm{~min}$ and washing was repeated once more then add $250 \mu \mathrm{L}$ of P-buffer $(100 \mathrm{mM}$ EDTA, $10 \mathrm{mM}$ Tris- $\mathrm{Cl}, 20 \mathrm{mM} \mathrm{NaCl}, 1 \% \mathrm{SDS})$. And the mix was incubated at $55^{\circ} \mathrm{C}$ for $1 \mathrm{~h}$. Following proteinase $\mathrm{K}$ digestion, $100 \mu \mathrm{L}$ of $5 \mathrm{M} \mathrm{NaCl}$ added to the samples. This mixture was vortexed vigorously for $15 \mathrm{sec}$ and centrifuged for $5 \mathrm{~min}$.

Supernatant was transferred to new eppendorf tube and the DNA precipitated using $1 \mathrm{~mL}$ of ice-cold 100\% ethanol. The precipitated mixture was kept on ice or at $-21^{\circ} \mathrm{C}$ for $5 \mathrm{~min}$ prior to centrifugation at $4^{\circ} \mathrm{C}$. The DNA was washed once with $70 \%$ ethanol, dried and suspended in $20 \mu \mathrm{L}$ of distilled $\mathrm{H}_{2} \mathrm{O}$.

Phenol-chloroform DNA extraction: This protocol was carried out according to the procedure described by John et al. (1991). About $100 \mathrm{~mL}$ blood collected into $1.5 \mathrm{~mL}$ of microcentrifuge tube. About $500 \mu \mathrm{L}$ of lysis buffer (Sucrose: $0.32 \mathrm{M}$, Tris-Hcl: $10 \mathrm{mM}, \mathrm{MgCl}_{2}$ :
$5 \mathrm{mM}$, Triton $\times 100: 1 \%$ ) was added, vortex and centrifuged $(12000 \times \mathrm{g})$ for $1 \mathrm{~min}$ and washing was repeated once more then $250 \mu \mathrm{L}$ of P-buffer (100 mM EDTA, $10 \mathrm{mM}$ Tris-Cl, $20 \mathrm{mM} \mathrm{NaCl}, 1 \% \mathrm{SDS}$ ). Following proteinase $\mathrm{K}$ digestion, samples were extracted with saturated phenol: chloroform ( $1: 1)$ followed by 2 extractions with chloroform. Transfer upper phase to a clean tube. The DNA was washed once with 70\% ethanol, The DNA was precipitated with 2 volumes of $100 \%$ ethanol and 0.1 volume of $3 \mathrm{M}$ sodium acetate $(\mathrm{pH} 5.2)$ and precipitated by centrifugation (15 min at $12,000 \times \mathrm{g}$ ). The DNA was washed once with $70 \%$ ethanol dried and suspended in $20 \mu \mathrm{L}$ of distilled $\mathrm{H}_{2} \mathrm{O}$.

Silica gel DNA extraction: This protocol was carried out according to the procedure described by Boom et al. (1990). About $100 \mathrm{~mL}$ blood collected into $1.5 \mathrm{~mL}$ of microcentrifuge tube. About $400 \mu \mathrm{L}$ of lysis reagent (Guanidin Thiocyanate: $20 \mathrm{mM}$, EDTA: $20 \mathrm{mM}$, Tris-Cl: $10 \mathrm{mM}_{\text {, TritonX }}$ :00 $40 \mathrm{~g} \mathrm{~L}^{-1}$, DTT: $10 \mathrm{~g} \mathrm{~L}^{-1}$ ) was added, vortex once more then was heated in $65^{\circ} \mathrm{C}$ for $5 \mathrm{~min}$, added $20 \mu \mathrm{L}$ of Nucleose solution (silica gel: $4 \mathrm{~g}$, Guanidin solution: $100 \mathrm{~mL}$ ) into tube and was mixed for $10 \mathrm{~min}$ and centrifugation $(10 \mathrm{sec}$ at $12,000 \times \mathrm{g})$ and then was added $200 \mu \mathrm{L}$ from Lysis reagent again. About $400 \mu \mathrm{L}$ Saline Buffer ( $1 \mathrm{M} \mathrm{NaCl}, 10 \mathrm{mM}$ Tris-Cl, $1 \mathrm{M} \mathrm{KCl}, 20 \mathrm{mM}$ EDTA) was added and was repeated once more then and centrifugation $(10 \mathrm{sec}$ at $5,000 \times \mathrm{g})$.

The DNA was precipitated with $45-55 \mu \mathrm{L}$ from extra gene (Ion Exchange Resin (chelex): 10\%, Orange G color: $0.02 \%$, Triton $\mathrm{X}_{100}: 0.01 \%$ ) and was incubated in $65^{\circ} \mathrm{C}$ at $3-5 \mathrm{~min}$ centrifugation ( $3 \mathrm{~min}$ at $1000 \times \mathrm{g}$ ) protein was precipitated and upper layer transmitted for other tube.

Calculation of DNA concentration: DNA concentrations were calculated by spectrophotometry by taking the Optical Density (OD) at a wavelength of $260 \mathrm{~nm}$. The concentrations of extracted DNA in each sample was determined with the formula $\mu \mathrm{g} \mathrm{mL} \mathrm{mL}^{-1}$ of $\mathrm{DNA}=\mathrm{A} 260 \times 50$ where 50 is a double-stranded DNA factor. The DNA was estimated from the ratio of absorbance at $260 / 280 \mathrm{~nm}$ with the mean of ten spectrophotometric readings.

Statistical analysis: Mean ( \pm standard deviation) extracted DNA concentrations and sample purities (A260: 280 ) for the 4 methods were compared analysis of variation samples with purity value $<1.6$ were considered to potentially have DNA value less than the calculated value and the Duncan test was used for post hoc identification of the methods with highest DNA yield by SPSS software.

PCR-RFLP: Amplified region is located in the intron between 2 exons of leptin. The genomic. The sequence of 
the forward and reverse primers, respectively were: Forward primer: 5'-TGGAGTGGCTTGTTATTTTCTTCT-3', Reverseprimer 3'-GTCCCCGCTTCTGGCTACCTAACT-3' PCR condition were $2.25 \mathrm{~mm} \mathrm{MgCl} 2,200 \mu \mathrm{m}$ dNTP, $1 \mu \mathrm{m}$ of each primer, 50-100 ng of genomic DNA and 0.2 Taq DNA polymerase.

The first cycle of PCR was $3 \mathrm{~min}$ at $94^{\circ} \mathrm{C}, 1 \mathrm{~min}$ at $55^{\circ} \mathrm{C}$ and $1 \mathrm{~min}$ at $72^{\circ} \mathrm{C}$ followed by 34 cycle of $45 \mathrm{sec}$ at $94^{\circ} \mathrm{C} 1 \mathrm{~min}$ at $55^{\circ} \mathrm{C}, 1 \mathrm{~min}$ at $72^{\circ} \mathrm{C}$ and ending with a $10 \mathrm{~min}$ extension phase at $72^{\circ} \mathrm{C} P C R$ product for each sample was digested with 10 unit of Sau3AI at $37^{\circ} \mathrm{C}$ for overnight gels were stained with $0.5 \mathrm{mg} \mathrm{L}^{-1}$ ethidium bromide for $20 \mathrm{~min}$. Distained and photographed.

\section{RESULTS AND DISCUSSION}

This study demonstrated that silica gel and phenol-chloroform methods are effective technique for extracting DNA from whole blood samples. Disadvantages to boiling method include the degradable DNA with higher than protein contamination (Fig. 1-3). Silica gel method resulted in significantly greater DNA yield and less protein contamination compared with other
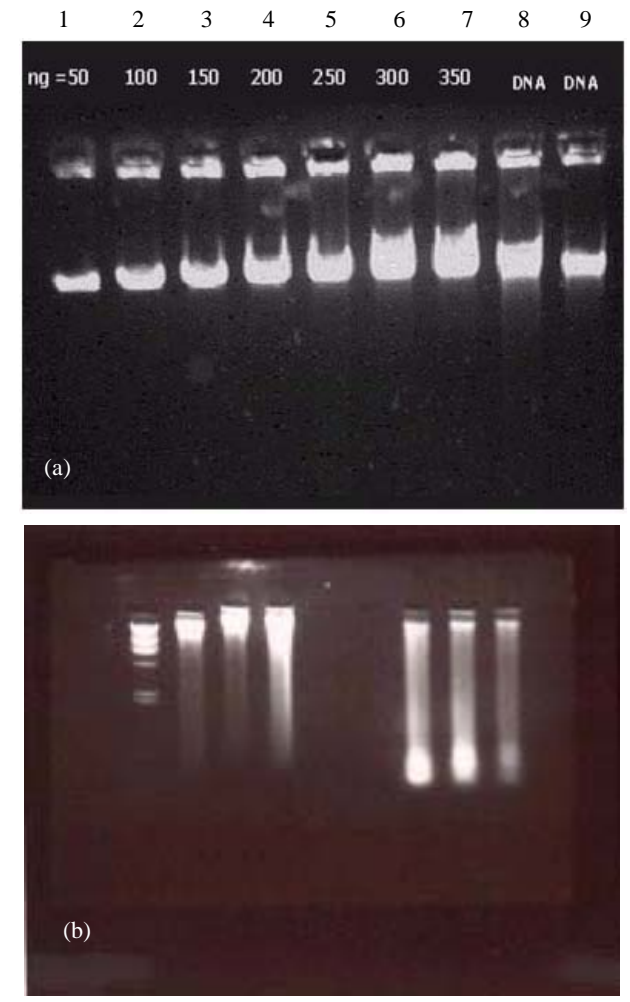

Fig. 1: Comparison of DNA extraction methods. Part (a) indicated silica gel methods and part (b) indicated phenol-chloroform, salting out and boiling methods, respectively

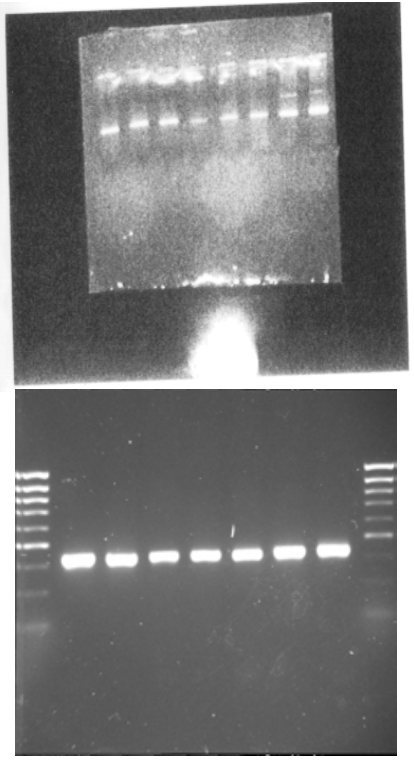

Fig. 2: The quality of PCR products that were extracted with different DNA extracted by different methods. PCR products with boiling extraction method (a) and PCR products with Silica gel extraction method (b)
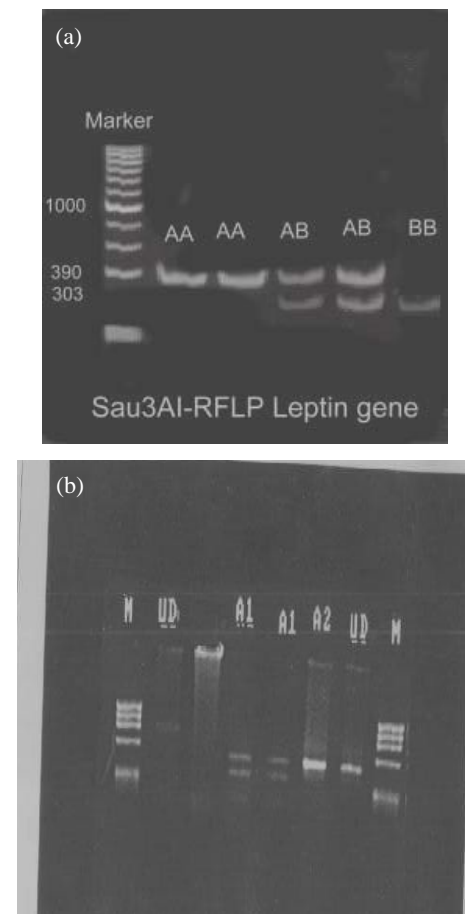

Fig. 3: The quality of digested PCR products that were extracted with different DNA extracted by different methods. RFLP fragments with boiling extraction method (a) and RFLP fragments with Silica gel extraction method (b) 
Table 1: DNA concentration $\left(\mu \mathrm{gL}^{-1}\right)$ and purity of DNA by 4 different methods

DNA extraction methods

Boiling

Salting out

Phenol-chloroform

Silica gel

All methods were performed in replication of 10 . Values given are mean $\pm \mathrm{SD}$;

$*$, ***Indicate that mean is significantly different $(p<0.05),(p<0.01)$, respectively

methods and also silica gel method is relatively simple and safe procedure that less time consuming. Although, all of methods have been shown to yield appropriately sized DNA produces for amplification fragments by PCR techniques. Mean \pm SD DNA concentrations and purities each DNA extraction methods are shown in Table 1.

\section{CONCLUSION}

In the study, all 4 methods yielded extraction products were successfully amplified by PCR for $422 \mathrm{bp}$ from leptin gene subjectively, the PCR products were most abundant for sample extracted by silica gel and phenol-chloroform techniques.

\section{ACKNOWLEDGEMENTS}

Researchers are thankful to the East Azarbyjan Management and Programming Center for support this project.

\section{REFERENCES}

Berthomieu, P. and C. Meyer, 1991. Direct amplification of plant genomic DNA from leaf and root pieces using PCR. Plant Mol. Biol., 17: 555-557.
Boom, R., C.J. Sol, M.M. Salimans, C.L. Jansen, P.M.W. van Dillen and J. van der Noordaa, 1990. Rapid and simple method for purification nucleic acid. J. Clin. Microbiol., 28: 495-503.

Chikuni, K., R. Tanabe, S. Muroya, Y. Fukumoto and S. Ozawa, 1997. A Simple method for genotyping the bovine growth hormone gene. Anim. Genet, 28: $230-232$.

Jeanpierre, M., 1987. A rapid method for the purification of DNA from blood. Nucleic Acids Res., 15: 9611-9611.

John, S.W.M., G. Weitzner, R. Rozen and C.R. Scriver, 1991. A rapid procedure for extracting genomic dna from leukocytes. Nucleic Acid Res., 19: 408-412.

Merante, F., S. Raha and M. Ling, 1999. Isolation of Total Cellular DNA from Tissue and Cultured Cells. In: Molecular Biomethods Handbook, Rapley, R. and J.M. Walker (Eds.). Humana Press Inc., Totowa.

Reymond, C.D., 1987. A rapid method for the preparation of multiple samples of eucaryotic DNA. Nucleic Acids Res., 15: 8118-8118.

Sambrook, J., E.F. Fritsch and T. Maniatis, 2000. Molecular Cloning: A Laboratory Manual. Cold Spring Harbor Laboratory Press, New York.

Williams, J.G.K., A.R. Kubelik, K.J. Livak, J.A. Rafalski and S.V. Tingey, 1990. DNA polymorphisms amplified by arbitrary primers are useful as genetic markers. Nucl. Acids Res., 18: 6531-6535. 